\title{
Thyroid Function in Children with Nephrotic Syndrome and Normal Renal Function in a Tertiary Level Hospital, Rajshahi
}

\author{
Khan Ishrat Jahan, ${ }^{1}$ Khondokar Shamim Parvez, ${ }^{2}$ Md. Sanaul Haque Mia, ${ }^{3}$ \\ Mohammad Mahbubur Rahman Khan, ${ }^{4}$ Md Jawadul Haque ${ }^{5}$
}

\begin{abstract}
Background: Nephrotic syndrome (NS) is a one of most common renal disease in children causing massive proteinuria. In patients with NS, other proteins like thyroid hormones and hormone binding protein are also lost in urine in addition to albuminuria. So, this study was done to find out the thyroid function status of nephrotic syndrome children and to compare the thyroid function of healthy control children.

Method: This cross sectional comparative study was carried out in the Department of Paediatrics, Rajshahi Medical College and Nuclear Medicine Centre, Rajshahi. Total 30 patients of both sex and age between 2-12 years diagnosed as nephrotic syndrome were included in this study and another 30 non-nephrotic syndrome apparently healthy children were taken as control. History, clinical examinations and laboratory investigations were recorded in preformed questionnaire. Thyroid function statuses also were evaluated in both patient and healthy control. After data collection, statistical analysis was done by computerized software.
\end{abstract}

Results: In this study, $63.3 \% \quad(n=19)$ nephrotic syndrome children had secondary hypothyroidism, overt hypothyroidism was $27.3 \%(n=7)$ and subclinical hypothyroidism was 6.7 $\%(n=2)$.

Conclusion: In patients of childhood nephrotic syndrome different forms of thyroid dysfunctions are commonly associated due to loss of thyroid hormones and hormone binding's protein.

Key words: Childhood nephrotic syndrome, thyroid hormones, secondary hypothyroidism, hypothyroidism and subclinical hypothyroidism.

TAJ 2018; 31: No-1: 62-69

\section{Introduction}

NS is a common renal disease. It is 15 times more common in children than adults. The incidence is 20-40/ million population and it varies in different part of the world. In USA the incidence is 20-70/ million population ${ }^{1}$ whereas it is $90-100 /$ million population in Indian subcontinent. In patients with proteinuria in nephrotic syndrome, many other proteins beside albumin are lost in the urine. Among these are hormones and hormone-binding proteins. Several studies ${ }^{2,3}$ have documented that urinary loss of thyroid hormones and thyroxinbinding globulin (TBG) in patients with proteinuria.

1 Junior Consultant, Department of Paediatrics, Rajshahi Medical College Hospital, Bangladesh

${ }^{2}$ Assistant Professor, Paediatric Nephrology, Rajshahi Medical College, Bangladesh

${ }^{3}$ Professor \& Head, Department of Paediatrics, Rajshahi Medical College. Bangladesh

${ }^{4}$ Professor, Department of Medicine, Rajshahi Medical College, Bangladesh

${ }^{5}$ Professor, Department of Community Medicine, Rajshahi Medical College. Bangladesh 
In patients with the nephrotic syndrome, loss of thyroid hormones may lead to low free thyroid hormone levels unless production is increased under the influence of thyroid-stimulating hormone (TSH). Furthermore, loss of albumin and TBG may reduce the binding capacity for thyroid hormones, resulting in a decrease in total triiodothyronine (T3) and thyroxin (T4) concentrations. ${ }^{4}$ Thyroid hormone in the circulation is bound to proteins, mainly thyroid binding globulin, prealbumin and albumin. In different studies ${ }^{4}$ reported that nephrotic syndrome results in urinary loss of intermediate sized plasma proteins (40-200 $\mathrm{kDa}$ ) and hormone binding proteins such as thyroxine binding globulin (TBG), transthyretin and albumin leading to reduction in thyroid hormones. ${ }^{4-5}$

Possibility of hypothyroidism in patients with nephrotic syndrome was reported 100 years above. $^{5}$ However symptoms of hypothyroidism with increased Thyroid-Stimulating Hormone (TSH) in children with nephrotic syndrome were discovered about 30 years later. ${ }^{6}$ In some study shows that existence of a hypothyroid state in some infants with NS; they recommended routine thyroid screening and early replacement therapy. ${ }^{7}$ Mild hypothyroidism in children with untreated NS, partly because of losses of T4, T3, free T4, free T3 and TBG in the urine. ${ }^{8}$ Nephrotic syndrome patients have an increased risk of subclinical hypothyroidism ${ }^{9}$ specifically, TSH levels were higher in patients with proteinuric renal diseases when compared with controls.,10 Proteinuria results in loss of thyroid hormone stimulating TSH production ${ }^{11}$. Mean value of serum T3 and T4 in children during nephrosis were within normal limit however mean value of thyroid stimulating hormone (TSH) was higher than normal level during nephrosis ${ }^{12}$ and also concluded that nephrotic syndrome commonly have a state of mild or sub-clinical hypothyroidism during proteinuria although they are clinically euthyroid.

This study was done to find out the thyroid status of NS children and to compare the thyroid function of healthy control children.

\section{Materials and Methods}

This was a cross sectional comparative study done in Department of Paediatrics, Rajshahi Medical College and Nuclear Medicine Centre, Rajshahi, during July 2014 to June 2016. Total 30 number of patients with childhood nephrotic syndrome who fulfill the inclusion and exclusion criteria were included as study subject of both sex and age between 2-12 yrs and another 30 non nephrotic syndrome apparently healthy children were be as control. Nephrotic syndrome was diagnosed according of to ISKDC criteria like oedema, urinary protein excretion $>1 \mathrm{gm} / \mathrm{m}^{2}$ body surface area/day, serum albumin $>2.5 \mathrm{gm} / \mathrm{dl}$ and serum cholesterol $>220 \mathrm{mg} / \mathrm{dl}$. Patients of secondary Nephrotic syndrome, renal failure, known case of thyroid disease and acute illness known to cause thyroid dysfunction are excluded from this study. After taken written consent from patient or legal guardian data were collected by history, clinical examinations and laboratory investigations. Thyroid function statuses were evaluated by measurement of S.T $\mathrm{T}_{4}, \mathrm{~T}_{3}$ and $\mathrm{TSH}$ level in Nuclear medicine centre in Rajshahi. After collecting data statistical analysis were done by help of SPSS software program version 16.0. Descriptive analytical techniques including frequency distribution, computation percentage, mean, SD etc were used. Association between variables was conducted by using Chi-square, student T-test and Pearson's correlation coefficient test as applicable. P-value $<0.05$ were be considered significant.

\section{Results}

Total 30 number of patients with childhood nephrotic syndrome were included as study subject of both sex and age between 2-12 yrs and another 30 non nephrotic syndrome apparently healthy children were be as control. Table-I showed baseline characteristics of patients and controls.

Table 1 


\begin{tabular}{|c|c|c|c|c|c|}
\hline \multicolumn{2}{|c|}{ Baseline characteristics } & \multicolumn{2}{|c|}{ Patient $(\mathrm{N}=30)$} & \multicolumn{2}{|c|}{ Control $(\mathrm{N}=30)$} \\
\hline & & $\mathrm{N}(\%)$ & Mean \pm SD & $\mathrm{N}(\%)$ & Mean \pm SD \\
\hline \multirow[t]{3}{*}{ Age (years) } & $2-5$ years & 16(53.4\%) & \multirow{3}{*}{$6.26 \pm 3.60$} & $18(60 \%)$ & \multirow{3}{*}{$5.85 \pm 2.91$} \\
\hline & 6-9 years & 11(36.6\%) & & $10(33.4 \%)$ & \\
\hline & $10+$ years & $3(10 \%)$ & & $2(6.6 \%)$ & \\
\hline \multirow[t]{2}{*}{ Sex } & Male & $21(70 \%)$ & & $20(66.6 \%)$ & \\
\hline & Female & $9(30 \%)$ & & $10(33.4 \%)$ & \\
\hline \multirow[t]{3}{*}{ BMI } & $\begin{array}{l}\text { 5th-84th percentile } \\
\text { (Healthy weight) }\end{array}$ & $14(46.7 \%)$ & \multirow{3}{*}{$78.50 \pm 17.62$} & $27(90.1 \%)$ & \multirow{3}{*}{$58.33 \pm 19.35$} \\
\hline & $\begin{array}{l}\text { 85th -94 th percentile } \\
\text { (Overweight) }\end{array}$ & $8(26.7 \%)$ & & $2(6.7 \%)$ & \\
\hline & $\begin{array}{l}>95 \text { th }+ \text { percentile } \\
\text { (Obese) }\end{array}$ & $8(26.7 \%)$ & & $1(3.3 \%)$ & \\
\hline
\end{tabular}

Here, mean $( \pm$ SD) age of patients with NS was $6.26( \pm 3.6)$ years. Mean $( \pm$ SD) age of healthy control was 5.85( \pm 2.91$)$ years. Male female ratio was 2.3:1 in patients with NS and 2:1 among healthy control. Most of patients were either overweight $(26.7 \%)$ or obese $(26.7 \%)$ whereas most of our healthy control were healthy weight (90.1\%).

Bar diagram showed that serum T4 was low in 26(86.6\%) NS patients and normal in all healthy controls in figure -1 .

Figure 1: serum T4

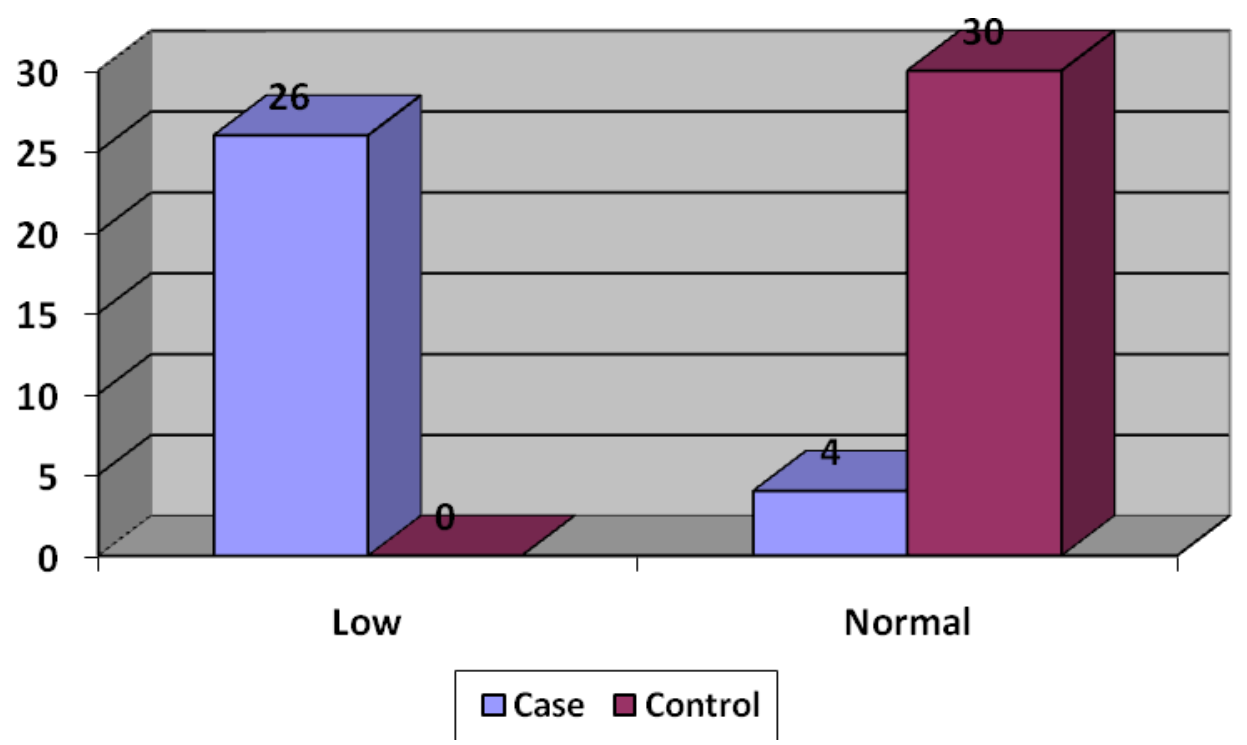

Serum T3 was low most of patients with NS (n 25, 83.3\%) and normal in 5(16.7\%) patients.

Figure 2: Serum T3 


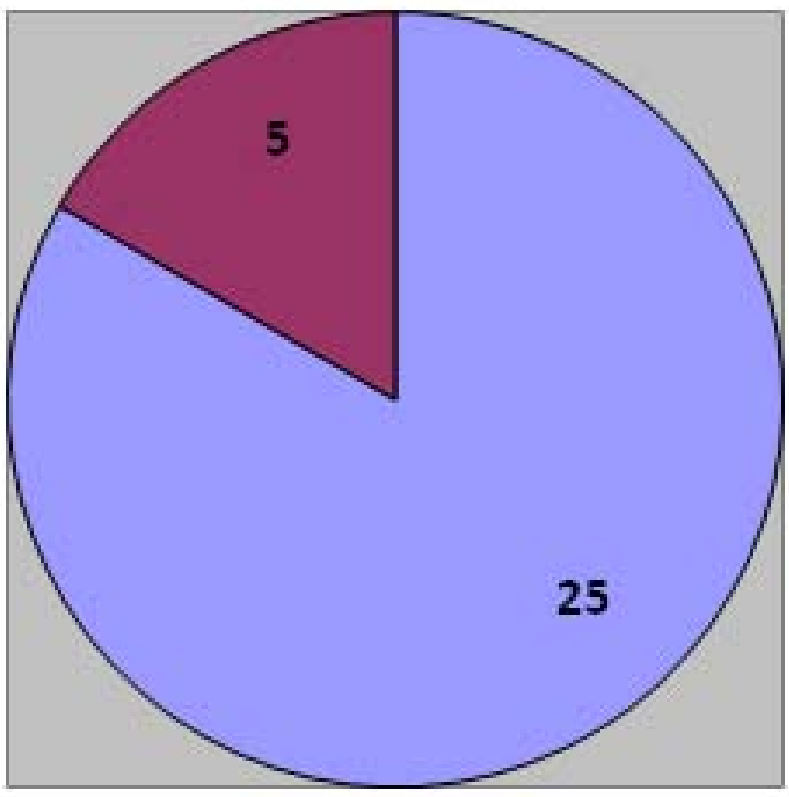

\section{$\square$ Low $\square$ Normal}

Figure 3: showing serum TSH in patient with NS and healthy control.

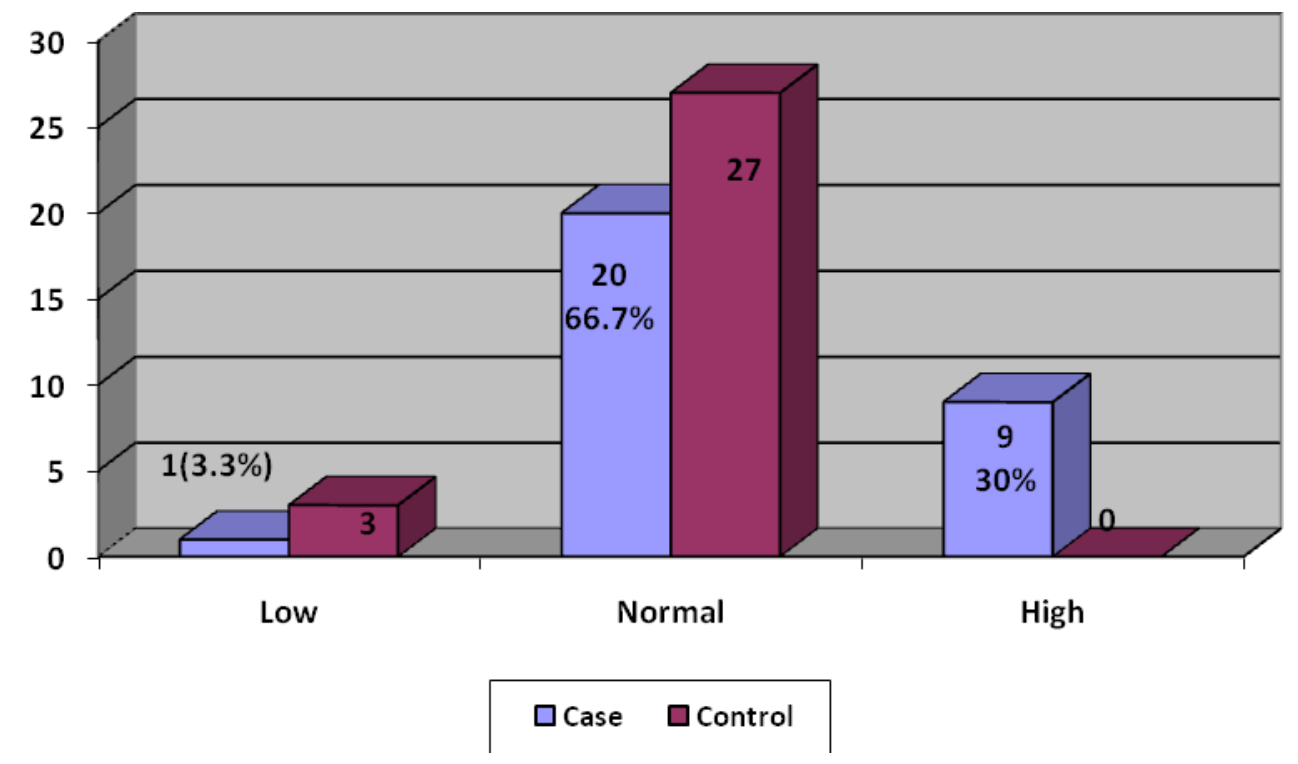


Serum TSH was normal in20 (66.7\%) number of nephrotic syndrome patients and high in 9 (30\%) patients and 1 had low serum TSH. In healthy control 27(90\%) had normal TSH and 3(10\%) had low TSH.

Table 2: Comparison of serum T4, T3 and TSH between patients with NS and Healthy control

\begin{tabular}{|c|c|c|c|c|c|c|c|}
\hline \multicolumn{3}{|c|}{ Thyroid hormone levels } & \multicolumn{2}{|c|}{ Patient $(\mathrm{N}=30)$} & \multicolumn{2}{|c|}{ Control $(\mathrm{N}=30)$} & \multirow[t]{2}{*}{$t(p)$} \\
\hline & & & $\mathrm{N}(\%)$ & Mean \pm SD & $\mathrm{N}(\%)$ & Mean \pm SD & \\
\hline \multirow{6}{*}{$\begin{array}{l}\mathrm{T} 4 \\
\text { (nmol/L) }\end{array}$} & \multirow{3}{*}{$\begin{array}{l}(2-3 \text { yrs }) \\
n=7\end{array}$} & $\begin{array}{l}\text { Low } \\
(<88)\end{array}$ & $7(23.3 \%)$ & \multirow{6}{*}{$36.72 \pm 27.46$} & 00 & \multirow{6}{*}{$107 \pm 12.11$} & \multirow{6}{*}{$\begin{array}{l}-12.972 \\
(<0.001)\end{array}$} \\
\hline & & $\begin{array}{l}\text { Normal } \\
(88-174)\end{array}$ & 00 & & $7(23.3 \%)$ & & \\
\hline & & $\begin{array}{l}\text { High } \\
(<174)\end{array}$ & 00 & & 00 & & \\
\hline & \multirow{3}{*}{$\begin{array}{l}\text { (>3 yrs) } \\
\mathrm{n}=23\end{array}$} & $\begin{array}{l}\text { Low } \\
(<71)\end{array}$ & $19(63.3 \%)$ & & 00 & & \\
\hline & & $\begin{array}{l}\text { Normal } \\
(71-165)\end{array}$ & $4(13.2 \%)$ & & $23(76.7 \%)$ & & \\
\hline & & $\begin{array}{l}\text { High } \\
(<165)\end{array}$ & 00 & & 00 & & \\
\hline \multirow{6}{*}{$\begin{array}{l}\mathrm{T} 3 \\
\text { (nmol/L }\end{array}$} & \multirow{3}{*}{$\begin{array}{l}\text { (2-5 yrs) } \\
\mathrm{n}=16)\end{array}$} & $\begin{array}{l}\text { Low } \\
(<1.54)\end{array}$ & $13(43.3 \%)$ & \multirow{6}{*}{$0.74 \pm 0.56$} & 00 & \multirow{6}{*}{$2.16 \pm 0.21$} & \multirow{6}{*}{$\begin{array}{l}-12.775 \\
(<0.001)\end{array}$} \\
\hline & & $\begin{array}{l}\text { Normal } \\
(1.54- \\
4.0)\end{array}$ & $3(10.9 \%)$ & & $18(60.0 \%)$ & & \\
\hline & & $\begin{array}{l}\text { High } \\
(<4.0)\end{array}$ & 00 & & 00 & & \\
\hline & \multirow{3}{*}{$\begin{array}{l}(>5 \mathrm{yrs}) \\
\mathrm{n}=14\end{array}$} & $\begin{array}{l}\text { Low } \\
(<1.39)\end{array}$ & $12(40.0 \%)$ & & 00 & & \\
\hline & & $\begin{array}{l}\text { Normal } \\
(1.39- \\
3.7)\end{array}$ & $2(6.7 \%)$ & & $12(40.0 \%)$ & & \\
\hline & & $\begin{array}{l}\text { High } \\
(<3.7)\end{array}$ & 00 & & 00 & & \\
\hline \multirow{3}{*}{$\begin{array}{l}\text { TSH } \\
(\mu \mathrm{lU} / \mathrm{L})\end{array}$} & & $\begin{array}{l}\text { Low } \\
(<0.7)\end{array}$ & $1(3.3 \%)$ & \multirow{3}{*}{$5.87 \pm 4.89$} & $3(10.0 \%)$ & \multirow{3}{*}{$1.80 \pm 0.65$} & \multirow{3}{*}{$\begin{array}{c}4.572 \\
(<0.001)\end{array}$} \\
\hline & & $\begin{array}{l}\text { Normal } \\
(0.7-6.4)\end{array}$ & $20(66.7 \%)$ & & $27(90.0 \%)$ & & \\
\hline & & $\begin{array}{l}\text { High } \\
(>6.4)\end{array}$ & $9(30.0 \%)$ & & 00 & & \\
\hline
\end{tabular}

Among the cases most of the patients had low T4 (n 26, 86.6\%), and normal T4 was 13.2\% (n 4). In case of TSH most of the patients had normal TSH (n-20, 66.7\%) and high in 30\% (n 9) of NS patients 
Figure 4: Thyroid status of NS patients (n-30)
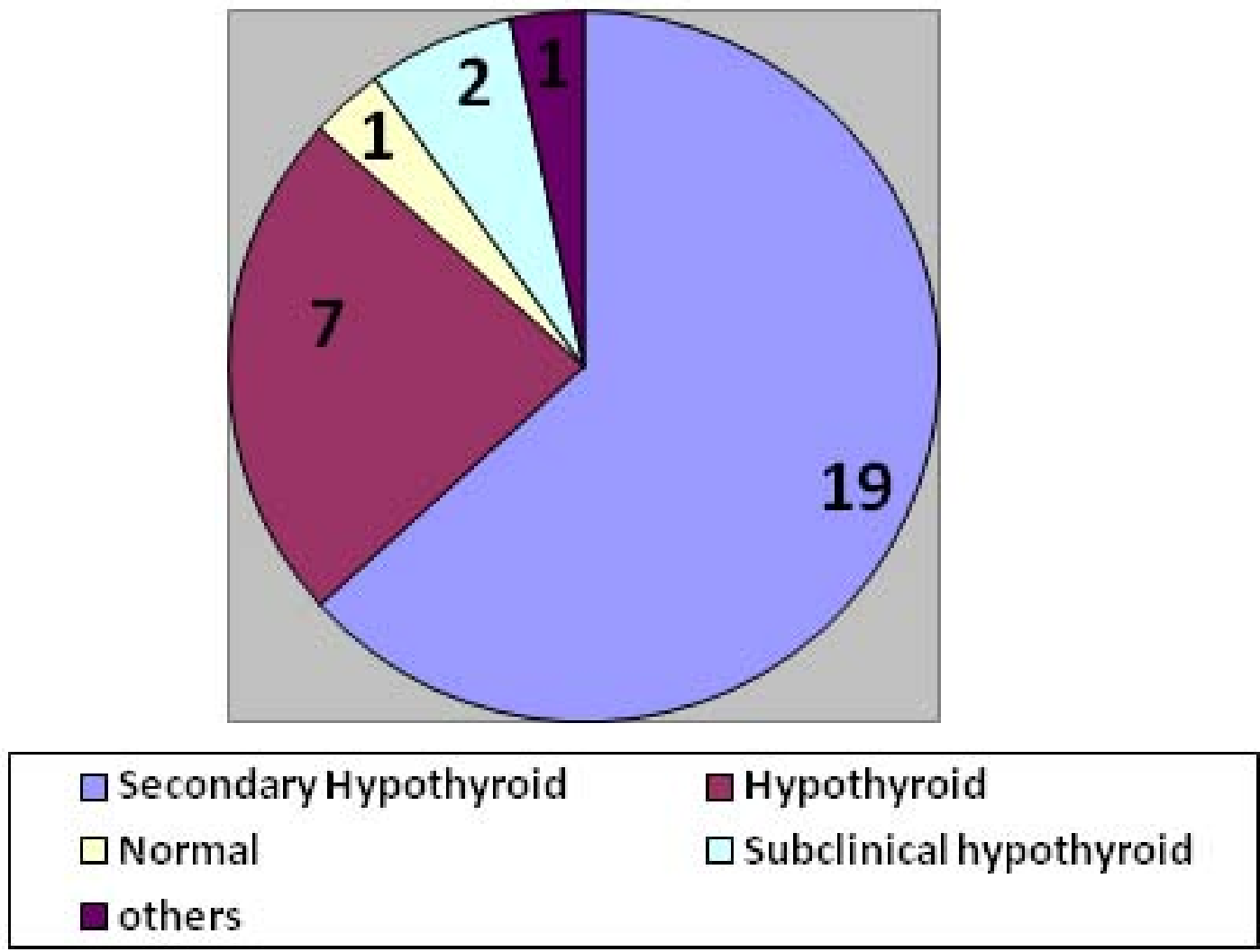

Among the cases most of the patients had secondary hypothyroid (n 19,63.3\%), overt hypothyroid was (n 7, 23.3\%). Other was subclinical hypothyroid (n 2, 6.7\%), and normal thyroid status was 1 (3.3\%).

\section{Discussion}

In our study highest frequency (53.4\%) of NS was observed in age $<5$ years. The mean $( \pm S D)$ age was $6.26 \pm 3.6$ years. Similar pattern of age distribution was observed in other studies., ${ }^{1,8,13}$ More male children were suffering from NS than female children. Boys and girls ratio in this study was 2.3:1. Similarly boys predominance was observed also in other studies. ${ }^{1,14,15}$

Proteinuria is associated with urinary excretion of thyroid hormones and thyroxine binding globulin (TBG). Relatively more hypoalbuminemia was also noted among children. ${ }^{1,3,8,16}$ Which is a universal finding., ${ }^{3,8,18}$ In some studies show that mean serum T4 \& T3 to be significantly lower and TSH to be significantly high in children with NS as compared to healthy subjects. ${ }^{8,12}$ After this study we have agreed upon the above findings but some degree of difference in observation was noted in other studies. ${ }^{3,8}$ In this study serum $\mathrm{T}_{3}$ was low most of patients with NS (n 25, 83.3\%), serum T4 was low in 26(86.6\%) NS patients and Serum TSH was normal in most $(66.7 \%, n$ 20) of the patients and high in 30\% (n 9). Unlike others study a significantly higher proportion of secondary hypothyroidism in 19 (63.3\%) patients was observed in this study, overt hypothyroidism was 7(23.3\%) and subclinical hypothyroid was 2 (6.7\%). Occurrence of overt hypothyroidism and subclinical hypothyroidism was also described by some studies ${ }^{3,8}$ but at much lower frequency. 
Overt hypothyroidism associated with NS should always be treated because overt hypothyroidism is associated with cardiovascular morbidity and mortality. But, whether subclinical hypothyroidism associated with NS should to be treated or not with L-thyroxine remains unclear. In some prospectively studied ${ }^{13} 35$ children with NS who also had subclinical hypothyroidism (mean $\mathrm{TSH}=8.93 \pm 3.15 \mu \mathrm{IU} / \mathrm{ml}$ ) during nephrosis. They found that this thyroid dysfunction resolves after remission of NS (mean TSH= $5.77 \pm 0.65 \mu \mathrm{IU} / \mathrm{ml}$ ). So, we concluded that subclinical hypothyroidism state in NS is temporary and improves with remission ${ }^{13}$ and no treatment is needed. On the contrary a trial of low dose L-thyroxine in 59 patient with primary NS and thyroid dysfunction small doses of L-thyroxine can influence remission of NS, in terms of shortening the course and improving the cure rate. ${ }^{20}$

\section{Conclusion}

Different forms of thyroid dysfunctions are associated with nephrotic syndrome. In patients with nephrotic syndrome large amount of protein is lost in urine along with thyroid hormones and hormone binding proteins. This hormone loss may lead to low T4, T3 and sometimes high or normal TSH level. NS was found to be associated with secondary and overt hypothyroidism and sometimes subclinical hypothyroidism. Considering the result of this study and observations done by other researchers it can be concluded that nephrotic range proteinuria is associated with thyroid hormone loss in urine and this can lead to significant reduction in serum T4, T3 and associate with normal or significant increase in serum TSH. So patients with NS can associate with secondary hypothyroidism or even overt hypothyroidism.

\section{Recommendations}

1. High index of suspicion is required to identify hypothyroidism in patients with NS and should be screened for thyroid status if proteinuria is heavy and prolonged.
2. Further evaluation for causes of secondary hypothyroidism in nephrotic syndrome patients (pituitatry or hypothalamus or any immunological factors that can affect both kidney and pituitary or hypothalamus) should be done.

3. A large population based study can be performed to see whether thyroid hormone replacement has any influence on NS who have thyroid dysfunction as hypothyroidism.

4. Every NS patient should be screened for Secondary hypothyroidism.

\section{Limitations of This Study}

It is a small scale cross sectional study. Other limitations of our study are patients and healthy controls are not screened for auto-immune thyroid disease (ie. Anti-TPO antibody) and FT4 \& FT3 were not measured.

\section{References}

1 Chowdhury EUA, Huq MN, Jaigirdar MA, 2010. Pattern of Nephrotic Syndrome in Children Admitted in Bangladesh Medical College Hospital. Bangladesh Med Coll J, 15(2):67-73.

2 Okpechil G, Rayner BL, 2010. Nephrotic Syndrome in Adult Black South African: HIV-Associated Nephropathy as the Main Culprit. Journal of National Medical Association, 102(12):1193-1197.

3 Afrasiabi MA, Vaziri ND, Gwinup G et al., 1979. Thyroid function studies in the nephrotic syndrome. Ann Int Med, 90:335-338.

4 Schussler GC. The thyroxine-binding proteins. Thyroid. 2000;10: 141-9.

5 Kaptein EM, Feinstein El \&Massry SG. Thyroid hormone metabolism in renal diseases. Contributions to Nephrology 198233 122-135.

6 Trouillier S, Delèvaux I, Rancé $N$, André $M$ Voinchet H, Aumaître O, 2008. Nephrotic syndrome: don't forget to search for hypothyroidism. Rev Med Interne, 29 (2):139-144.

7 Mooraki A, Broumand B, Neekdoost F, Amirmokri $P$, Bastani $B, 2003$. Reversible acute renal failure associated with hypothyroidism: report of four cases with a brief review of literature. Nephrology, 8:57-60. 
8 Ito S, Kano K, Ando T, Ichimura T, 1994. Thyroid function in children with nephrotic syndrome. PediatrNephrol, 8:412-415.

9 B.U.Sawanl, G.D. Nadkarni, U.R. Thakare. and G.R. Rajan. Changes in lipid peroxidation \& free redical scavengers in kidney of hypothyroid and hyperthyroid. pp. 1334-1337. 2003.

10 Gilles R, den Heijer M, Ross AH, Sweep FCGJ, Hermus ARMM, Wetzels JFM, 2008. Thyroid function in patients with proteinuria, Netherlands the journal of Medicine, 66(11):483-485.

11 Iglesias P, Díez JJ, 2009. Thyroid dysfunction and kidney disease. European Journal of Endocrinology, 160:503-515.

12 Afroz S, Khan AH, Roy DK. Thyroid function in children with nephrotic syndrome. Mymensingh Med J. 2011;20(3):407-11.

13 Chadha V, Alon US, 1999. Bilateral nephrectomy reverses hypothyroidism in congenital nephrotic syndrome. PediatrNephrol, 13:209-211.

14 Shahni V, Nanda S, Gehlawat VK, Gathwala G, 2014. Hypothyroidism in nephrotic syndrome in children. IOSR-JDMS, 13(8):7-11.

15 Tarik MH, Ekram ARMS, Haque MA, Islam AKMM, Uddin MJ, 2007. Renal Pathology in Adult Onset
Idiopathic Nephrotic Syndrome: A Study of 100 cases. TAJ, 20(2):140-143.

16 Sah JP, Pandey R, Jaiswal S, Sharma B, Chaudhury SS, 2013. Correlation of hypoproteinemia and hypoalbuminemia with hypercholesterolemia in the children with nephrotic syndrome. STM Journals, 3(2):1-11.

17 Oguz Y, Yilmaz MI, Acikel C, Eyileten T, Caglar K, Oktenli C, Yenicesu M, Vural A, 2009. The relationship between adiponectin levels and degree of proteinuria in patients with nephrotic and nonnephrotic proteinuria. Renal Failure, 31:29-35.

18 Fonseca V, Thomas $M$, Katrak A, Sweny $P$, Moorhead JF, 1991. Can urinary thyroid hormone loss cause hypothyroidism? Lancet, 338(8765):475476.

19 Gavin LA, Mcmahon FA, Castle JN, Cavalieri RR, 1978. Alterations in serum thyroid hormones and thyroxine-binding globulin in patients with nephrosis. J ClinEndocrinolMetab, 46:125-130.

20. Feinstein EI, Kaptein EM, Nicoloff JT, Massry SG, 1982. Thyroid function in patients with nephrotic syndrome and normal renal function. American Journal of Nephrology, 2:70-76.
All correspondence to-

Dr. Khan Ishrat Jahan Junior Consultant, Department of Paediatrics, Rajshahi Medical College Hospital, Bangladesh. Email: khan.ishratjahandr234@gmail.com 